\title{
A Common Amino Acid Polymorphism in Insulin Receptor Substrate-1 Causes Impaired Insulin Signaling \\ Evidence from Transfection Studies
}

\author{
Katrine Almind, ${ }^{\ddagger}$ Gen Inoue, ${ }^{*}$ Oluf Pedersen, ${ }^{\ddagger}$ and C. Ronald Kahn* \\ * Research Division, Joslin Diabetes Center and Department of Medicine, Harvard Medical School, Boston, Massachusetts 02215; and \\ ${ }^{\ddagger}$ Steno Diabetes Center and Hagedorn Research Institute, 2820 Gentofte, Copenhagen, Denmark
}

\begin{abstract}
Insulin receptor substrate-1 (IRS-1) is the major cytoplasmic substrate of the insulin and IGF-1 receptors. Recent studies have identified multiple sequence variants of IRS-1, especially in patients with non-insulin-dependent diabetes mellitus. In the present study, we have examined insulinstimulated processes in $32 \mathrm{D}$ (IR) cells, a myeloid progenitor cell stably overexpressing the insulin receptor, transfected with wild-type human-IRS-1 or the most common human variant of IRS-1 in which glycine 972 is replaced by arginine. As compared to wild-type IRS-1, insulin stimulation of cells transfected with mutant IRS-1 exhibited a 32\% decrease in incorporation of $\left[{ }^{3} \mathrm{H}\right]$ thymidine into DNA $(P=0.002)$, a $36 \%$ decrease in IRS-1 associated phosphatidylinositol (PI) 3 -kinase activity $(P=0.004)$ and a $25 \%$ decrease in binding of the p85 regulatory subunit of PI 3-kinase to IRS-1 ( $P=$ 0.002). There was also a tendency for a decrease in Grb2 binding to IRS-1 and insulin-stimulated mitogen-activated protein kinase activity, however, these were not statistically significant. The changes occurred with no change in insulin receptor or IRS-1 tyrosine phosphorylation. These data indicate that the mutation in codon 972 in IRS-1 impairs insulin-stimulated signaling, especially along the PI 3-kinase pathway, and may contribute to insulin resistance in normal and diabetic populations. (J Clin. Invest. 1996. 97:25692575.) Key words: diabetes mellitus - IRS-1 • insulin resistance $\cdot$ genetics $・$ PI 3-kinase
\end{abstract}

\section{Introduction}

The primary substrate of the insulin receptor in most tissues is insulin receptor substrate-1 (IRS-1). ${ }^{1}$ By genetic analysis of insulin-resistant non-insulin-dependent diabetes mellitus (NIDDM) patients and normal individuals, we recently discovered four polymorphisms in IRS-1 (1). Two of these were silent, while two predicted amino acid substitutions. One of

Address correspondence to C. Ronald Kahn, M.D., Research Division, Joslin Diabetes Center, One Joslin Place, Boston, MA 02115. Phone: 617-732-2635; FAX: 617-732-2593.

Received for publication 10 November 1995 and accepted in revised form 15 March 1996.

1. Abbreviations used in this paper: IRS-1, insulin receptor substrate-1; MAP, mitogen-activated protein; NIDDM, non-insulin-dependent diabetes mellitus; PI 3-kinase, phosphatidylinositol 3-kinase.

J. Clin. Invest.

(C) The American Society for Clinical Investigation, Inc.

0021-9738/96/06/2569/07 \$2.00

Volume 97, Number 11, June 1996, 2569-2575 these was at codon 513 (numbered according to Nishiyama and Wands, reference 2) and resulted in a proline for alanine substitution; the other was at codon 972 and predicted a replacement of glycine by arginine. Several subsequent studies (3-9) in different ethnic groups have confirmed these and other polymorphisms in IRS-1, and when grouped together show that the overall frequency of the codon 972 variant is $10.7 \%$ in NIDDM patients versus $5.8 \%$ in control subjects $(P<0.02)$, suggesting that this genetic variant is a potential contributor to the insulin resistance in NIDDM (7). Moreover, in a recent study of the IRS-1 polymorphism in a random sample of 380 young, healthy adults, the IRS-1 polymorphism at codon 972 in its heterozygous form was shown to potentiate obesity-linked insulin resistance (10). Multivariate analysis substantiated that the combination of obesity and the codon 972 variant was associated with a $50 \%$ reduction in insulin sensitivity $(P=0.0008)$. The same obese subjects were characterized by a clustering of metabolic cardiovascular risk factors with elevated fasting levels of plasma glucose, serum triglyceride, plasma tPA, and plasma PAI-1 activity. One lean male homozygous for the codon 972 mutation had impaired insulin sensitivity and developed transient diabetes after a 24-h dexamethasone load (10).

Despite the multiple population studies investigating polymorphisms in IRS-1, the effect of these sequence variations on insulin signaling has not been determined. IRS-1 is tyrosine phosphorylated on multiple sites after stimulation by insulin, insulin-like growth factor-1 (IGF-1), and IL-4 (11). These phosphorylation sites then serve as docking sites for several proteins possessing SH2 domains. Thus, phosphorylated IRS-1 binds to and stimulates phosphatidylinositol (PI) 3-kinase, SHPTP-2, and via GRb2-SOS the Ras and mitogen-activated protein (MAP) kinase pathways (11-18). Although Gly ${ }^{972}$ is not directly located in a phosphorylation site, it is conserved in human, rat, and murine IRS- 1 and lies between two potential sites of tyrosine phosphorylation involved in binding the p85 subunit of PI 3-kinase. The aim of the present study was to determine if and/or how cells expressing the variant IRS- 1 would change insulin-stimulated signaling. Since cells taken from the patients are usually heterozygous for IRS-1 mutation and also possess IRS-2, complicating any analysis using patient cells, for these experiments we used cultured cells lacking both IRS-1 and -2 which were transfected with normal and mutants IRS-1s, as well as the normal human insulin receptor.

\section{Methods}

Reagents. Restriction endonucleases were obtained from New England BioLabs Inc., Beverly, MA. Leupeptin, aprotinin, DTT, PMSF, protein kinase inhibitor, and myelin basic protein were from Sigma Chemical Co., St. Louis, MO and protein A Sepharose 6MB from Pharmacia, Uppsala, Sweden. Immobilon polyvinylidne diflouride (PVDF) transfer membranes were from Millipore Corp., Bedford, 
MA. Antibodies to the COOH-terminal peptide of IRS-1 were raised as previously described (19). Antibodies to baculovirus produced ratIRS-1 and phosphotyrosine antibody (4G10) were provided by M.F. White (Joslin Diabetes Center, Boston, MA). Anti-rat PI 3-kinase antibody, rabbit antiserum to $\mathrm{p} 85$, and Grb2 antibody were from Upstate Biotechnology Inc., Lake Placid, NY. Anti-MAP kinase antibodies were prepared as previously described (20). Thymidine, [methyl $\left.-{ }^{3} \mathrm{H}\right]$, nucleoside triphosphate $\left[{ }^{32} \mathrm{P}\right]$, and enhanced chemiluminescence reagents were from NEN-DuPont, Wilmington, DE. ${ }^{125}$ I-protein A was from ICN Biomedicals Costa Mesa, CA. Human recombinant insulin was from Boehringer Mannheim Biochemica, Mannheim, Germany, and phosphotidylinositol was from Avanti Polar Lipids, Alabaster, AL. The retroviral pBABE-Puromycin expression vector and the BOSC23 packaging cell line were gifts from Dr. D. Baltimore (Massachusetts Institute of Technology, Cambridge, MA).

Cell culture. The 32D cell line is a myeloid progenitor cell which is dependent on IL-3 for its proliferation and survival $(21,22)$. 32D cells do not proliferate upon exposure to IL-4 or insulin, although $32 \mathrm{D}$ cells have $\sim 1,200$ IL- 4 and $\sim 500$ insulin receptors. This lack of sensitivity to IL-4 and insulin can be explained by a lack of the insulin and IL-4 receptor substrates IRS-1 and IRS-2 (21). 32D cells were grown in $5 \% \mathrm{CO}_{2}$ in RPMI 1640 containing $10 \%$ FBS and $5 \%$ WEHI-conditioned medium. WEHI cells produce IL-3, and the medium extracted from confluent flasks of WEHI cells is used as an IL-3 supplement for the 32D cells.

Construction of IRS-1 cDNAs. The cDNA construct containing the mutation in IRS- 1 was created by site-directed mutagenesis by overlap extension using the polymerase chain reaction (23). Two complimentary oligonucleotide primers containing the nucleotide substitution at the first position of codon 972 were used for the PCR to create the nucleotide substitution. cDNA containing the full-length open reading frame of human IRS-1 in pBluescript was used as a template. The PCR fragment containing the codon 972 variant in IRS-1 was digested with BclI and NheI and inserted in place of the wildtype sequence. The new construct was confirmed by nucleotide sequencing (Sequenase 2.0; U.S. Biochemical Corp., Cleveland, $\mathrm{OH}$ ).

Transfection of IRS-1 cDNA to $32 \mathrm{D}$ cells. The IRS- 1 cDNAs containing wild-type or mutant IRS-1 were digested at the EcoRI and SalI sites and inserted into the retroviral pBABE-puromycin expression vector $(24,25)$ at the same sites. The BOSC23 packaging cell line, was maintained in DME containing $10 \% \mathrm{FBS}$ at $37^{\circ} \mathrm{C}$ in a humidified atmosphere of $10 \% \mathrm{CO}_{2}(25)$. BOSC23 cells $\left(2 \times 10^{6}\right.$ in a $60-$ $\mathrm{mm}$ dish) were transfected by calcium phosphate coprecipitation with $10 \mu \mathrm{g}$ of $\mathrm{pBABE} / \mathrm{wtIRS}-1$ or $\mathrm{pBABE} / \mathrm{R}^{972} \mathrm{IRS}-1$. The medium was removed $48 \mathrm{~h}$ after transduction, and $4 \times 10^{6} 32 \mathrm{D}$ or $32 \mathrm{D}$ (IR) cells (a cell line overexpressing insulin receptor, line $286.5 \mathrm{w} 3$ ) were added to the dish for $24 \mathrm{~h}$, then transferred to a clean dish. After $24 \mathrm{~h}$, the cells were spun down and selected in $2 \mu \mathrm{g} / \mathrm{ml}$ puromycin. Stable cell lines were maintained in RPMI 1640 containing 10\% FBS, 5\% WEHI at $37^{\circ} \mathrm{C}$ in a humidified atmosphere of $5 \% \mathrm{CO}_{2}$. Equivalent numbers of cells from each cell line were collected and lysed for $10 \mathrm{~min}$ in $1 \mathrm{ml}$ of lysis buffer to give final concentrations of $20 \mathrm{mM}$ Tris, $\mathrm{pH} \mathrm{7.5,137}$ $\mathrm{mM} \mathrm{NaCl}, 1 \mathrm{mM} \mathrm{MgCl} 2,1 \mathrm{mM} \mathrm{CaCl} 2,1 \%$ NP-40, $10 \%$ glycerol, 10 $\mu \mathrm{g} / \mathrm{ml}$ aprotinin $10 \mu \mathrm{g} / \mathrm{ml}$ leupeptin, $100 \mu \mathrm{M}$ sodium orthovanadate $\left(\mathrm{Na}_{3} \mathrm{VO}_{4}\right)$, and $1 \mathrm{mM}$ PMSF. Insoluble material was removed by centrifugation in a microfuge for $10 \mathrm{~min}$ at $4^{\circ} \mathrm{C}$. The supernatant was denatured by boiling in Laemmli sample buffer containing $100 \mathrm{mM}$ DTT and separated by SDS PAGE. Gels were transferred to Immobilon PVDF transfer membranes, blocked, and probed with the indicated antibody (see below). The blots were washed and then incubated with $2 \mu \mathrm{Ci}$ of ${ }^{125} \mathrm{I}$-protein $\mathrm{A}[30 \mu \mathrm{Ci} / \mu \mathrm{g}]$, washed again, and imaged on a Molecular Dynamics Phosphorimager (Molecular Dynamics Inc., Sunnyvale, CA).

Expression of insulin receptors and IRS-1. Expression of IRS-1 in 32D(IR) cells after retroviral transduction and selection was an efficient and reproducible process. The amounts of insulin receptor and IRS-1 protein expressed and quantitated by immunoblotting were similar among the cell lines (Table I). Similar levels of expression
Table I. IRS-1 and Insulin Receptor Protein Levels in Transfected 32D(IR) Cells

\begin{tabular}{lcc}
\hline Cell line & IRS-1 expression & IR expression \\
\hline & $\%$ & $\%$ \\
WT-1 & 100 & 100 \\
WT-2 & 97 & 92 \\
$972-1$ & 166 & 95 \\
$972-2$ & 167 & 78 \\
\hline
\end{tabular}

Protein expression was measured by performing SDS-PAGE followed by IRS-1 immunoblotting of cell lysates from 32D(IR) cells transfected with $\mathrm{pBABE} / \mathrm{IRS}-1$ constructs. Immunoblots were quantitated using a Phosphorimager. The amount of protein is expressed as percent of control (WT-1).

were obtained for cells expressing the codon 513 IRS-1 mutant in 32D(IR) cells (results not shown).

Incorporation of ${ }^{3} H$ thymidine into DNA in $32 D(I R)$ cells. Cells in log phase growth were washed twice and $2 \times 10^{5}$ cells were seeded in $1 \mathrm{ml}$ of medium into each of 24 wells containing RPMI with $10 \%$ FBS alone or containing various concentrations of insulin or $5 \%$ WEHI (26). Cells were grown for $48 \mathrm{~h}$ in a $37^{\circ} \mathrm{C}$ incubator. $\left[{ }^{3} \mathrm{H}\right]$ thymidine was added to a final concentration of $0.5 \mu \mathrm{Ci} / \mathrm{ml}$, and the incubation continued for $3 \mathrm{~h}$. Cells were collected onto glass microfiber filters. The cells were lysed, and unincorporated nucleotide was removed by washing with water. The filters were counted in scintillation fluid for $1 \mathrm{~min}$.

In vivo IRS-1 phosphorylation and associated PI 3-kinase activity. The cell lines were grown to confluency whereupon $5 \times 10^{7}$ cells were collected by low-speed centrifugation and then starved for $4 \mathrm{~h}$ in $\mathrm{DME}$ at $37^{\circ} \mathrm{C}$. Cells were stimulated with $100 \mathrm{nM}$ insulin for $10 \mathrm{~min}$, collected, and lysed in $1 \mathrm{ml}$ of ice-cold lysis buffer containing final concentrations of $50 \mathrm{mM}$ Hepes, $\mathrm{pH} 7.6,1 \%$ Triton X-100 $150 \mathrm{mM}$ $\mathrm{NaCl}, 10 \mu \mathrm{g} / \mathrm{ml}$ aprotinin, $10 \mu \mathrm{g} / \mathrm{ml}$ leupeptin, $100 \mu \mathrm{M} \mathrm{Na}_{3} \mathrm{VO}_{4}, 1 \mathrm{mM}$ PMSF, $100 \mathrm{mM} \mathrm{NaF}, 10 \mathrm{mM}$ sodium pyrophosphate, and $4 \mathrm{mM}$ EDTA for $10 \mathrm{~min}$ at $4^{\circ} \mathrm{C}$. The tubes were centrifuged for $10 \mathrm{~min}$, and supernatants containing $750 \mu \mathrm{g}$ total protein were incubated with anti-IRS-1 COOH-terminal antibody $(6 \mu \mathrm{g} / \mathrm{ml})$ for $75 \mathrm{~min}$. Immune complexes were collected with $60 \mu \mathrm{l}$ of a $50 \%$ slurry of protein A sepharose. The immunoprecipitates were washed three times in PBS containing 1\% NP-40, $10 \mu \mathrm{g} / \mathrm{ml}$ aprotinin, $10 \mu \mathrm{g} / \mathrm{ml}$ leupeptin, and $100 \mu \mathrm{M} \mathrm{Na}_{3} \mathrm{VO}_{4}$, three times in $0.5 \mathrm{M} \mathrm{LiCl}, 0.1 \mathrm{M}$ Tris, $\mathrm{pH} 7.5,10 \mu \mathrm{g} / \mathrm{ml}$ aprotinin, 10 $\mu \mathrm{g} / \mathrm{ml}$ leupeptin, and $100 \mu \mathrm{M} \mathrm{Na}_{3} \mathrm{VO}_{4}$, and twice in $10 \mathrm{mM}$ Tris, $\mathrm{pH}$ 7.5, $100 \mathrm{mM} \mathrm{NaCl}, 1 \mathrm{mM}$ EDTA, $10 \mu \mathrm{g} / \mathrm{ml}$ aprotinin, $10 \mu \mathrm{g} / \mathrm{ml} \mathrm{leu}-$ peptin, and $100 \mu \mathrm{M} \mathrm{Na} \mathrm{VO}_{4}$. The pellets were resuspended in $50 \mu \mathrm{l}$ of $10 \mathrm{mM}$ Tris, pH 7.5, $100 \mathrm{mM} \mathrm{NaCl}, 1 \mathrm{mM}$ EDTA, $100 \mu \mathrm{M} \mathrm{Na}_{3} \mathrm{VO}_{4}$, $10 \mu \mathrm{l}$ of $100 \mathrm{mM} \mathrm{MgCl}$, and $10 \mu \mathrm{l}$ of $2 \mu \mathrm{g} / \mu \mathrm{l}$ phosphotidylinositol, and finally sonicated in $10 \mathrm{mM}$ Tris, $\mathrm{pH} 7.5$, containing $1 \mathrm{mM}$ EGTA. The PI 3-kinase reaction was initiated by addition of $5 \mu \mathrm{l}$ of $880 \mu \mathrm{M}$ ATP, $20 \mathrm{mM} \mathrm{MgCl}$ containing $35 \mu \mathrm{Ci}\left[{ }^{32} \mathrm{P}\right] \mathrm{ATP}(3,000 \mathrm{Ci} / \mathrm{mmol})$ per tube. After vortexing vigorously for $10 \mathrm{~min}$, the reaction was stopped by addition of $20 \mu 18 \mathrm{~N} \mathrm{HCl}$ and $160 \mu \mathrm{l}$ of $\mathrm{CHCl}_{3}$ :methanol (1:1). The samples were centrifuged for $10 \mathrm{~min}$ and the lower organic phase spotted onto a silica gel TLC plate previously coated with $1 \%$ potassium peroxalate. TLC plates were developed in $\mathrm{CHCl}_{3}:$ methanol: $\mathrm{H}_{2} \mathrm{O}: \mathrm{NH}_{4} \mathrm{OH}$ (ratio 120:94:23.2:4), dried, and visualized by autoradiography. Phosphorylated phosphatidylinositol was quantitated with the Phosphorimager.

Immunoprecipitation and immunoblotting. Each cell line was stimulated for $2 \mathrm{~min}$ for quantitating IRS-1 phosphorylation and p85 binding or for $0,1,3.5$, or 10 min for determination of Grb2 binding, and lysed as described above. Supernatants were immunoprecipitated with anti-IRS-1 antibody (1:100) and $750 \mu \mathrm{g}$ of total protein was re- 
solved by SDS-PAGE and transferred to PVDF paper. The IRS-1 immunoprecipitates for measuring p85 binding were blotted with $\mathrm{p} 85$ antibody (1:1,000 dilution). Aliquots of IRS-1 immunoprecipitates for quantitating IRS-1 phosphorylation were blotted with rat-IRS-1 antibody and with a phosphotyrosine antibody (1:500) followed by blotting with anti-mouse $\operatorname{IgG}$ antibody $(1: 1,000)$ raised in rabbit. The blots were then incubated with $2 \mu \mathrm{Ci}$ of ${ }^{125} \mathrm{I}$-protein $\mathrm{A}[30 \mu \mathrm{Ci} / \mu \mathrm{g}]$. Detection and quantitation were performed on a Phosphorimager as previously described (27). IRS-1 immunoprecipitates for determination of IRS-1/Grb2 association were blotted with Grb2 antibody (1:300), detected by immunoblotting with anti-rabbit IgG coupled to peroxidase, and developed with enhanced chemiluminescence reagents as described by manufacturer. These blots were quantitated by scanning densitometry.

MAP kinase assay. Serum-starved cells were treated with $10^{-7} \mathrm{M}$ insulin at $37^{\circ} \mathrm{C}$ for $5 \mathrm{~min}$, lysed, and immunoprecipitated with antiMAP kinase antibody followed by protein A sepharose incubation as previously described. The immunoprecipitates were washed three times with lysis buffer and twice with $40 \mathrm{mM}$ Hepes, $\mathrm{pH}$ 8.0, $10 \mathrm{mM}$ $\mathrm{MgCl}_{2}$ (kinase reaction buffer). The reactions were initiated by adding kinase reaction buffer containing $0.25 \mathrm{mg} / \mathrm{ml}$ myelin basic protein, $2 \mu \mathrm{M}$ protein kinase inhibitor, and $50 \mu \mathrm{M}\left[\gamma^{-}{ }^{32} \mathrm{P}\right] \mathrm{ATP}$, in a final vol of $40 \mu \mathrm{l}$. The reactions were allowed to proceed for $10 \mathrm{~min}$ at $30^{\circ} \mathrm{C}$ then stopped by the addition of $20 \mu \mathrm{l}$ of $3 \times$ Laemmli buffer containing $300 \mathrm{mM}$ DTT. The mixtures were boiled for $5 \mathrm{~min}$ and subjected to SDS-PAGE in $12.5 \%$ polyacrylamide gels.

Statistics. Differences between the cell lines were tested by the unpaired or paired Student's $t$ test where appropriate. Data in figures are given as mean \pm standard error of the mean.

\section{Results}

Incorporation of $\left[{ }^{3} H\right]$ thymidine into DNA. 32D cell lines require IL-3 and serum for growth, and maximal proliferation of the cells is obtained by maintenance in FBS and IL-3. Thus, for each cell line, the incorporation of $\left[\right.$ methyl $\left.-{ }^{3} \mathrm{H}\right]$ thymidine into DNA of transfected and nontransfected 32D and 32D(IR) cells, respectively, was measured at insulin concentrations ranging from 0 to $1,000 \mathrm{nM}$ and expressed as a percentage of maximal proliferation stimulated by IL-3. Nontransfected 32D cells with a low number of endogenous insulin receptors did not proliferate upon exposure to insulin and 32D(IR) cells stably transfected with human insulin receptor showed only a minimal mitogenic response to insulin (Fig. 1). Likewise, transfection of 32D cells with IRS-1 alone conferred only modest increase in insulin-mediated incorporation of thymidine into DNA, with a maximal increase of $20 \%$ above basal (results not shown). However, coexpression of insulin receptor and IRS-1 resulted in a significant response to insulin with a maximum of $70 \%$ of the IL-3 response. Insulin-stimulated thymidine incorporation progressed in the same fashion for every IRS-1 expressing cell line, although the cell lines expressing the Gly $\rightarrow$ Arg substitution of codon 972 had an average 32\% decrease in maximal insulin-stimulated mitogenesis. Similar results were observed in two independent cell lines expressing the mutant IRS-1. A paired Student's $t$ test for all points from 0.01 to $1,000 \mathrm{nM}$ demonstrated a significant difference $(P=$ $0.002)$ between cell lines expressing mutated and wild-typeIRS-1. By contrast, cells expressing the codon 513 mutation showed no decrease in proliferation compared to wild-type expressing cell lines (results not shown).

PI 3-kinase activity in IRS-1 immunoprecipitates from insulin stimulated $32 D(I R)$ cells expressing wildtype-IRS-1 or $R^{972}$ $I R S-1$. To determine the mechanism of the reduced insulin

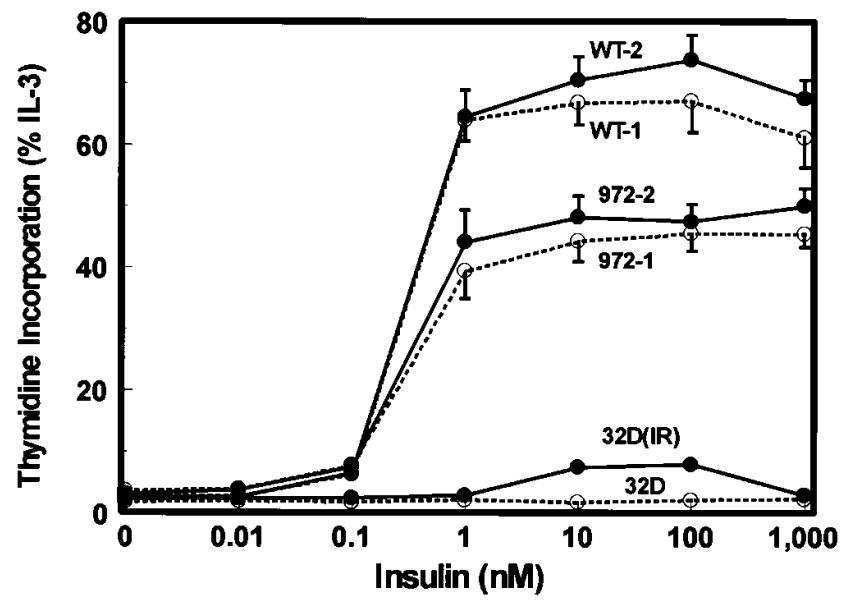

Figure 1. DNA synthesis in response to insulin in $32 \mathrm{D}$ and $32 \mathrm{D}$ (IR) cells expressing wild-type IRS-1 or mutated R ${ }^{972}$ IRS- $1 .\left[{ }^{3} \mathrm{H}\right]$ thymidine incorporation into DNA was measured $48 \mathrm{~h}$ after insulin stimulation as described in Methods. The data points represent the mean of three independent experiments each done in triplicate. Results are expressed as percentage of $\left[{ }^{3} \mathrm{H}\right]$ thymidine uptake of the cell lines stimulated with IL-3.

effect on DNA synthesis in the presence of the mutant IRS-1, a series of early steps in insulin action was studied. PI 3-kinase activity was measured by counting ${ }^{32} \mathrm{P}$ incorporated into phosphatidylinositol in vitro using anti-IRS-1 immunoprecipitates.

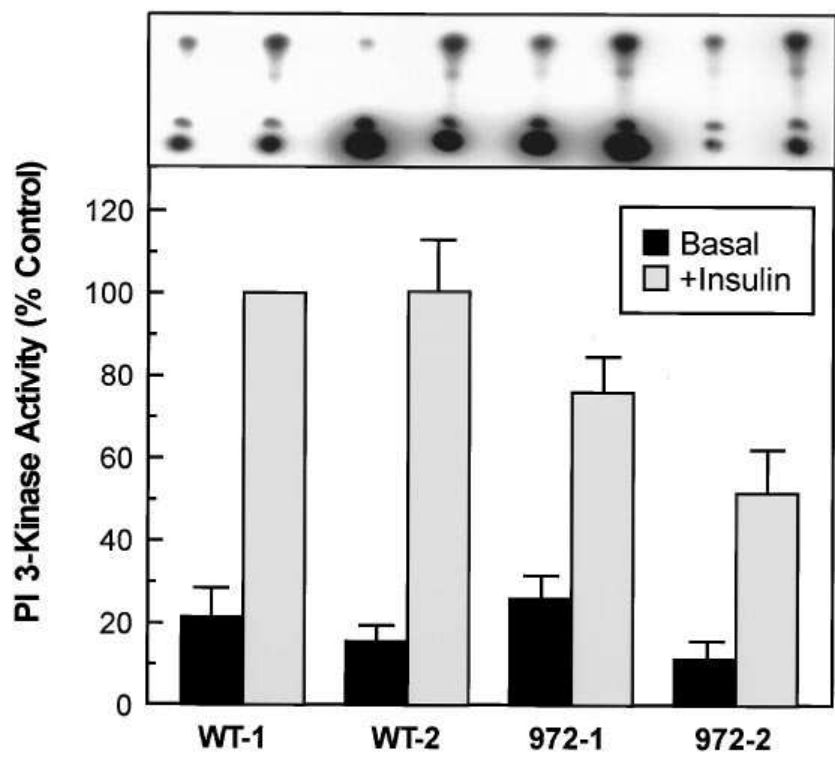

Figure 2. IRS-1 associated PI 3-kinase activity in 32D(IR) cells transfected with wild-type IRS-1 or R ${ }^{972}$ IRS-1. (Top) PI-3-32 P produced during PI 3-kinase assay in anti-IRS-1 immunoprecipitates from two independent cell lines expressing wild-type IRS-1 (WT-1 and WT-2) and two independent cell lines expressing $\mathrm{R}^{972}$ IRS-1 (972-1 and 972-2) as analyzed by thin layer chromatography and autoradiography. (Bottom) PI-3-kinase activity was determined as shown in top panel and quantified using a Phosphorimager. Data represent three independent experiments each in duplicate and are expressed as percentage of control (WT-1). Basal PI 3-kinase activity for $\mathrm{WT}=$ 21.3 \pm 4.5 and $\mathrm{R}^{972}$ IRS- $1=21.0 \pm 4.3$. Insulin-stimulated PI 3-kinase activity for $\mathrm{WT}=102.5 \pm 5.1$ and $\mathrm{R}^{972} \mathrm{IRS}-1=66.8 \pm 9.1(P=0.004)$ expressed as mean \pm SEM. 
A

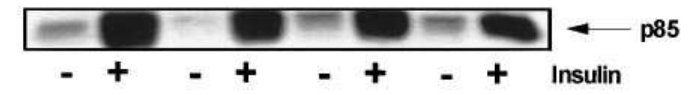

B

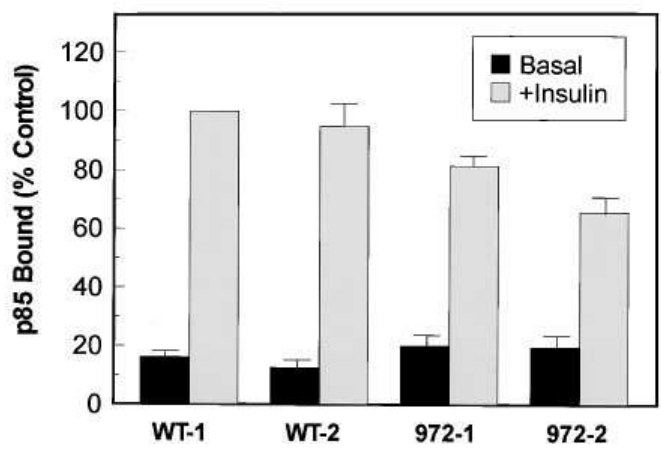

Figure 3. Binding of $\mathrm{p} 85$ of PI 3-kinase to IRS-1 in 32D(IR) cells expressing wild-type IRS-1 or R ${ }^{972}$ IRS-1. ( $A$ ) Supernatants from transfected 32D(IR) cells were immunoprecipitated with IRS-1 antibody and immunoblotted with p85 antibody. (B) p85 protein levels in IRS-1 immunoprecipitates quantified using a Phosphorimager. Data represent four independent experiments expressed as percent of control $(W T-1)$. Basal $\mathrm{p} 85$ binding for $\mathrm{WT}=14.3 \pm 2$ and $\mathrm{R}^{972} \mathrm{IRS}-1=$ $19.8 \pm 2.2$. Insulin stimulated $\mathrm{p} 85$ binding for $W T=97.5 \pm 4.5$ and $\mathrm{R}^{972}$ IRS- $1=73.6 \pm 4.2(P=0.002)$ expressed as mean \pm SEM.

A representative autoradiogram of a TLC-plate is shown in Fig. 2 (top). Quantitation of the radioactivity incorporated into phosphatidylinositol revealed that the cells expressing wildtype and the mutated $\mathrm{R}^{972} \mathrm{IRS}-1$ had a similar low level of basal PI 3-kinase activity (Fig. 2, bottom). Insulin stimulation of cells expressing wild-type-IRS-1 increased the IRS-1-associated PI 3-kinase activity by 4.8 -fold after insulin stimulation. In $\mathrm{R}^{972}$ IRS-1 expressing cells, maximal insulin-stimulated activity was decreased by $36 \%$ as compared to supernatants from cells expressing wild-type-IRS-1 $(P=0.004)$.

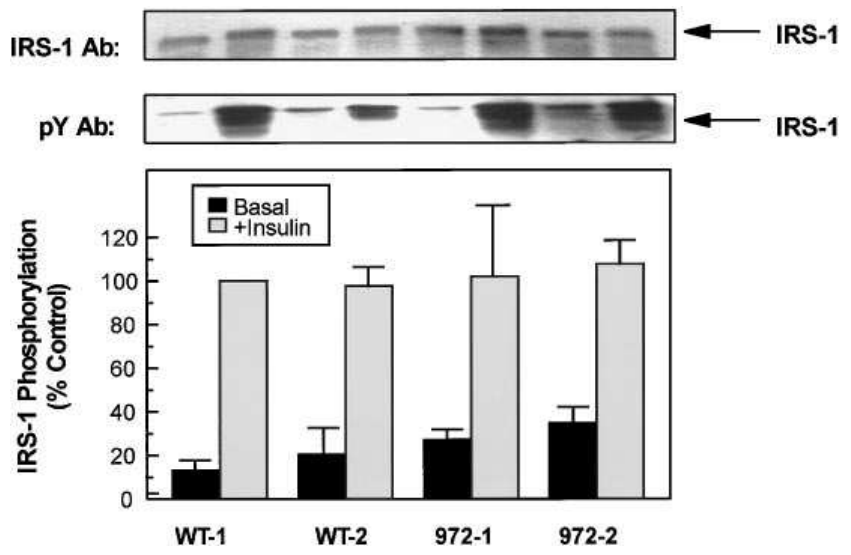

Figure 4. Phosphorylation of wild-type IRS- 1 and $\mathrm{R}^{972}-1$ expressed in $32 \mathrm{D}$ (IR) cells. (Top) Immunoblots of equal amounts of total protein from IRS-1 immunoprecipitates with anti-IRS-1 antibody. (Middle) Blotting of equal amounts of total protein from IRS-1 immunoprecipitates with anti-phosphotyrosine $(p Y)$ antibody. (Bottom) IRS-1 phosphorylation quantified using a Phosphorimager. Data represent four independent experiments expressed as percent of control (WT-1). Basal IRS-1 phosphorylation for WT $=16.3 \pm 5.9$ and $\mathrm{R}^{972} \mathrm{IRS}-1=30.9 \pm 5.3$. Insulin stimulated IRS-1 phosphorylation for $\mathrm{WT}=99.0 \pm 4.2$ and $\mathrm{R}^{972} \mathrm{IRS}-1=104.9 \pm 14.2$ expressed as mean \pm SEM.
IRS-1 expression, phosphorylation, and binding of p85 of PI 3-kinase. To determine if the reduced PI 3-kinase activity in cells expressing the 972 mutant resulted from a diminished interaction between insulin receptor and $R^{972}$ IRS- 1 or from decreased binding of $\mathrm{p} 85 \alpha$ to $\mathrm{R}^{972}$ IRS-1, equal amounts of total protein were immunoprecipitated with anti-IRS-1 antibody and subjected to SDS-PAGE and immunoblotting with p85 antibody (Fig. $3 A$ ). As previously described, insulin induced binding of p85 to IRS-1. Quantitation of the protein bands confirmed that after insulin stimulation, binding of $\mathrm{p} 85$ protein to IRS-1 in insulin-stimulated wild-type cells was increased 6.8 -fold. In cells expressing mutated $\mathrm{R}^{972} \mathrm{IRS}-1$ binding of $\mathrm{p} 85$ to IRS-1 was decreased by $25 \%(P=0.002)$ as compared to cells expressing wild-type protein. The decrease was not due to a decrease in IRS-1 protein or its phosphorylation. Western blots of lysates from insulin-stimulated cells and from nonstimulated cells revealed equal amounts of IRS-1 protein (Fig. 4, top). Phosphorylation of tyrosine residues on IRS-1, as measured by phosphotyrosine immunoblots, also showed no change after 2 min of insulin stimulation (Fig. 4, middle).

Insulin-stimulated binding of Grb2 and MAP-kinase activity. Insulin stimulation of $32 \mathrm{D}$ (IR) cells transfected with IRS-1 results in a IRS-1-Grb2 association and activation of MAPkinase (18). To determine whether the amino acid variant had any influence on the association between Grb2 and IRS-1, IRS-1 immunoprecipitates were analyzed for Grb2 binding by immunoblotting with a Grb2 antibody. Fig. $5 \mathrm{~A}$ shows a time course of IRS-1 tyrosine phosphorylation and Grb2 association. With both wild-type and mutant IRS-1, tyrosine phosphorylation, and Grb2 binding were maximal within 1 min of insulin stimulation and sustained for at least $10 \mathrm{~min}$. Quantita-

A

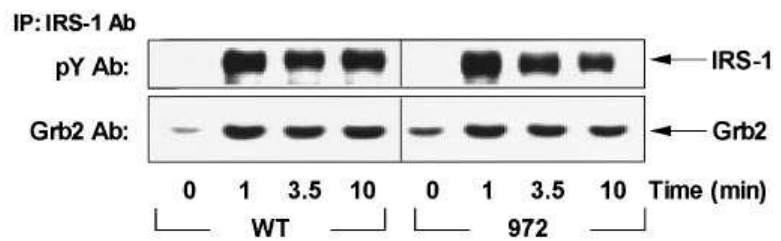

B

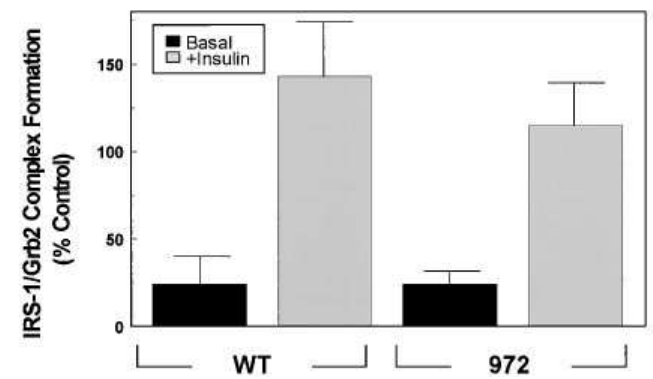

Figure 5. Time course of IRS-1 tyrosine phosphorylation and IRS-1/ Grb2 complex formation. ( $A$ ) IRS-1 was immunoprecipitated after insulin stimulation, and the resulting precipitates were analyzed by SDS-PAGE and blotting with anti-phosphotyrosine $(p Y)$ antibody (top) or anti-Grb2 antibody (bottom) in 32D(IR) cells expressing wild-type or $\mathrm{R}^{972}$ IRS-1 after $0,1,3.5$, and 10 min of insulin stimulation. (B) Grb2 protein levels in IRS-1 immunoprecipitates were quantitated using a Phosphorimager. Data represent two independent experiments expressed as percentage of control (WT-1). Basal Grb2 binding for $\mathrm{WT}=24.4 \pm 12.3$ and $\mathrm{R}^{972} \mathrm{IRS}-1=24.4 \pm 7.5$. Insulin stimulated Grb2 binding for WT $=142.7 \pm 30.9$ and $\mathrm{R}^{972} \mathrm{IRS}-1=$ $114.9 \pm 23.9$ expressed as mean \pm SEM. 
A

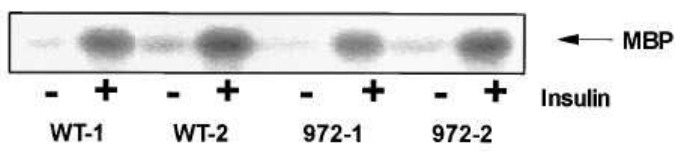

B

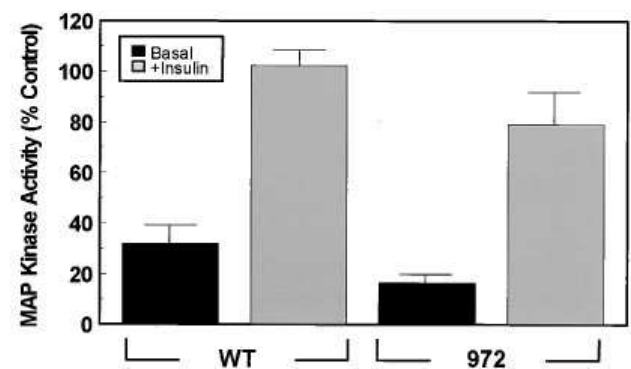

Figure 6. MAP-kinase activation in lysates from cells expressing wild-type IRS-1 or $\mathrm{R}^{972}$ IRS-1. ( $A$ ) Phosphorylation of myelin basic protein $(M B P)$ in MAP-kinase immunoprecipitates from nonstimulated or insulin-stimulated cells expressing wild-type IRS-1 and $\mathrm{R}^{972}$ IRS-1. (B) MAP-kinase activity measured as the phosphorylation and quantitated using a Phosphorimager. Data represent two independent experiments expressed as percent of control (WT-1). Basal MAP-kinase activation for WT $=31.9 \pm 8.2$ and $\mathrm{R}^{972}$ IRS- $1=$ 16.3 \pm 3.3 . Insulin stimulated MAP-kinase activity for $\mathrm{WT}=$ $102.2 \pm 4.9$ and $\mathrm{R}^{972} \mathrm{IRS}-1=79.1 \pm 10.5$.

tion of multiple experiments indicated a trend toward a lower level of Grb2-IRS-1 association, however, they did not reach statistical significance. To assess MAP kinase activity, lysates from insulin-stimulated and nonstimulated cells were immunoprecipitated with a MAP-kinase antibody and activity was measured by myelin basic protein phosphorylation in vitro. Again, cells transfected with mutated IRS-1 tended to be lower in MAP-kinase activity as compared to cells transfected with wildtype-IRS-1, however this change was also not statistically significant (Fig. 6).

\section{Discussion}

Analysis of the gene encoding IRS-1 has revealed several mutations resulting in amino acid substitutions. The most prevalent amino acid change in IRS-1 is a glycine to arginine change at codon 972. The occurrence of this amino acid polymorphism has been examined in more than 1,500 NIDDM patients and control subjects from different ethnic groups. Overall, the frequency of the Gly ${ }^{972} \rightarrow$ Arg amino acid substitution is $\sim 6 \%$ in normal populations and is increased in NIDDM patients by about twofold (7), suggesting that mutation of the IRS-1 gene may act as a risk factor predisposing to NIDDM. Equilibrium glucose infusion rates during a euglycemic clamp in both NIDDM patients and controls with the codon 972 variant are lower than those in comparable groups without IRS-1 mutations (28). In nondiabetic obese individuals, the codon $972 \mathrm{mu}-$ tation, in association with obesity, is associated with a potentiation of the obesity-linked insulin resistance (10). However, functional studies were needed to confirm whether there is a direct impact of this genetic variant on insulin sensitivity or whether the amino acid polymorphism is just a marker for a linked genetic factor.

IRS-1 is considered the major insulin receptor substrate in most insulin-sensitive tissues. IRS-1 is required for the insulin- mediated cellular effects including activation of PI 3-kinase (29), p70 S6 kinase (11), and for the cellular events leading to mitogenesis (30). The importance of IRS-1 in in vivo insulin signaling has been most directly demonstrated in mice made deficient in IRS-1 using targeted gene knockout by homologous recombination $(31,32)$. IRS-1-deficient mice have a $50 \%$ reduction in intrauterine growth, impaired glucose tolerance, and a decrease in insulin and IGF-1-stimulated glucose uptake. The residual insulin/IGF-1 action in these mice is linked to the presence of IRS-2 (33). This second insulin receptor substrate has an overall identity to IRS- 1 of $43 \%$ and is also expressed in many tissues (34). IRS-2 shows increased insulinstimulated tyrosine phosphorylation in IRS-1-deficient mice and under these biological conditions acts as an alternative substrate for the insulin receptor. 32D cells lack both IRS-1 and IRS-2 and, thus, are ideal to demonstrate the insulin-mediated response transmitted through these substrates after transfection with either wild-type or mutant IRS-1.

Our results confirm that expression of wild-type IRS-1 in 32D(IR) cells restores the proliferative response to insulin as previously shown (21). Expression of IRS-1 containing the mutation in codon 972 similarly results in insulin-stimulated mitogenesis, however, the maximal incorporation of thymidine into DNA is decreased by $32 \%$ as compared to cells expressing wild-type IRS-1. In an attempt to elucidate at which step the insulin-mediated signal is decreased, we examined several insulin-signaling proteins. As noted above, tyrosine phosphorylated IRS-1 associates with PI 3-kinase which in turn acts as an important upstream element in signaling to glucose transporter translocation, p70 S6 kinase, DNA synthesis, and glycogen synthesis $(35,36)$. We therefore determined the PI 3-kinase activity directly associated with IRS-1 by performing the PI 3-kinase assays on IRS-1 immunoprecipitates. After insulin stimulation there is a 5-fold increase in IRS-1-associated PI 3-kinase activity in cells expressing wild-type IRS-1. Cells expressing mutated $\mathrm{R}^{972}$ IRS- 1 have a $36 \%$ reduction in IRS1-associated PI 3-kinase activity when compared to cells transfected with wild-type IRS-1. This decrease in PI 3-kinase activity is a consequence of a diminished interaction between PI 3 -kinase and IRS-1, which is reduced by $\sim 25 \%$ in cells expressing $\mathrm{R}^{972}$ IRS-1.

The exact reason for the decrease in IRS-1/p85 binding is not clear. The association of IRS-1 and PI 3-kinase is mediated by binding of $\mathrm{SH} 2$ domains of the $85-\mathrm{kD}$ regulatory subunit (p85 $\alpha$ ) to tyrosyl phosphorylated YMXM motifs of IRS-1 (12). Although some activation of PI 3-kinase occurs by the occupancy of only one SH2 domain, full activation of PI 3-kinase requires occupancy of both SH2 domains (37). Codon 972 of IRS-1 is located between two YMXM sites ( $\mathrm{Y}^{939}$ and $\mathrm{Y}^{987}$ ) which when phosphorylated are known to bind p85 (11). A diminished binding of p85 to IRS- 1 containing the Gly $\rightarrow$ Arg substitution could be due to an effect of the mutation on the tertiary structure of IRS-1. It is also possible that the amino acid substitution prevents the interaction of one of the YMXM motifs with the SH2 domain or prevents the binding of both domains at the same time, thus reducing the affinity of p85 for IRS-1.

While the IRS-1 amino acid substitution has a negative effect on $\mathrm{p} 85$ binding, this protein modification does not have an impact on the interaction of the insulin receptor kinase with IRS-1, which results in phosphorylation of IRS-1. Indeed, insulin-stimulated tyrosine phosphorylation of IRS- 1 is the same in 
all cell lines. Insulin receptor autophosphorylation is also similar. These results are not surprising since codon 972 is not directly within a tyrosine phosphorylation site nor within the more $\mathrm{NH}_{2}$-terminal regions of IRS-1, which are thought to be involved in the interaction with the insulin receptor kinase (38). Since the exact stoichiometry of phosphorylation is difficult to determine, it is possible that there is a decrease in phosphorylation of one or more tyrosine residues in the cells expressing $\mathrm{R}^{972}$ IRS- 1 which is undetected by the methods used in this study. Ultimately, it may be relevant to map the phosphorylation sites, as well as study the structure of the variant molecules.

The tendency toward a decrease in Grb2 association and MAP kinase activation in cells expressing the mutant IRS-1 might suggest a more general conformational change in IRS-1 due to the amino acid substitution; however, neither of these biochemical measures were statistically different in cells expressing mutant IRS- 1 . Whether more sensitive assays could define some alterations in these pathways remains to be determined. In either case, our results suggest that the Grb2-RasMAP kinase pathway is less influenced by the codon 972 amino acid substitution than the pathway leading to PI 3-kinase activation, in which two YMXM motifs of IRS-1 are involved.

This study is the first functional study of a naturally occurring amino acid polymorphism in IRS-1. The mutant studied has been shown to be more frequent in persons with NIDDM than normals and is associated with an accentuation of the insulin resistance in obese, otherwise healthy, young adults (10). Ura et al. (28) have also found the 972 variant of IRS-1 to be increased in Japanese with NIDDM, and in this setting associated with an $\sim 25 \%$ further decrease in insulin sensitivity. A recent study by Goodyear et al. (40) has also suggested that the deficiency in insulin action in human obesity may result from a decrease in IRS-1 related PI 3-kinase signaling, but in this case the decrease appears to be in IRS-1 protein expression. IRS-1 phosphorylation and PI 3-kinase activation have also been shown to be defective in several animal models of diabetes and insulin resistance (41). Since most patients with NIDDM have a normal IRS-1 molecule or are only heterozygous for these mutations, other factors must contribute to the insulin resistance. These include insulin receptor down-regulation (40), defects in GLUT4 glucose transporter translocation (40), alterations of plasma membrane lipids (42), elevated expression of TNF- $\alpha$ in adipose tissue (43), increased expression of the membrane glycoprotein PC-1 (44), and overexpression of the Ras-related cytosolic protein rad (45). The current study clearly established that the 972 variant of IRS-1 may also confer cellular insulin resistance, in part through a defective interaction between the mutant IRS-1 and the regulatory subunit of PI 3-kinase. Since PI 3-kinase activation appears essential in several insulin-mediated intracellular processes, including translocation of the insulin-responsive glucose transporter, Glut 4, to the plasma membrane (35), defects in PI 3-kinase could lead to insulin resistance in glucose metabolism.

In nonobese humans, however, the impact of IRS-1 mutations may be somewhat limited by the presence of alternative pathways of signaling. In the IRS- 1 knockout mouse, insulin and IGF-1 signaling is reduced $\sim 50 \%$; however, there is significant residual signaling via IRS-2 (33). Likewise, we have previously reported a young healthy and lean male who carries the codon 972 variant on both alleles. Although he exhibited insulin resistance, low fasting serum insulin levels, and a low acute insulin response, his glucose tolerance was only minimally abnormal (10). However, after a 24-h dexamethasone load he developed transient diabetes. Taken together with the data of the present study, we suggest that sequence variation in IRS-1 may contribute significantly to insulin resistance, but alone may be insufficient to result in clinical diabetes mellitus. Since IRS-1 is ubiquitously expressed in insulin and IGF-1sensitive tissues, including the $\alpha$ - and $\beta$-cells of the islets of Langerhans, however, it is possible that the presence of the codon 972 variant may also affect islet cell differentiation, maturation, or function, and thereby diminish the $\beta$-cells response. Indeed, Rothenberg et al. have shown that glucose-stimulated insulin secretion by pancreatic $\beta$-cells seems to be modulated by autocrine activation of the insulin-signaling pathway involving tyrosine phosphorylation of IRS-1 and activation of PI 3-kinase (46). Thus, in humans, the defective interaction between IRS-1 and PI 3-kinase in the codon 972 variant may contribute to both the peripheral tissue insulin resistance and the impaired insulin secretion.

\section{Acknowledgments}

The authors also wish to thank M. Myers, J. Bruening, M.E. Patti, and $\mathrm{J}$. Moyers for advice in various aspects of the experiments.

This work was supported in part by the Danish Diabetes Association and the Danish Medical Research Council and by National Institutes of Health Grant DK33201 (to C.R. Kahn), Joslin's Diabetes and Endocrinology Research Center Grant DK 36836. Dr. Inoue is a Sankyo/ Joslin Fellow.

\section{References}

1. Almind, K., C. Bjorbaek, H. Vestergaard, T. Hansen, S. Echwald, and O. Pedersen. 1993. Aminoacid polymorphisms of insulin receptor substrate-1 in non-insulin-dependent diabetes mellitus. Lancet. 342:828-832.

2. Nishiyama, M., and J.R. Wands. 1992. Cloning and increased expression of an insulin receptor substrate-1-like gene in human hepatocellular carcinoma. Biochem. Biophys. Res. Commun. 183:280-285.

3. Hager, J., H. Zouali, G. Velho, and P. Froguel. 1993. Insulin receptor substrate (IRS-1) gene polymorphisms in French NIDDM families. Lancet. 342: 1430-1432.

4. Laakso, M., M. Malkki, P. Kekalainen, J. Kuusisto, and S.S. Deeb. 1994. Insulin receptor substrate-1 variants in non-insulin-dependent diabetes. J. Clin. Invest. 94:1141-1146.

5. Imai, Y., A. Fusco, Y. Suzuki, M.A. Lesniak, R. D'Alfonso, G. Sesti, A. Bertoli, R. Lauro, D. Accili, and S.I. Taylor. 1994. Variant sequences of insulin receptor substrate-1 in patients with noninsulin-dependent diabetes mellitus. $J$. Clin. Endocrinol. \& Metab. 79:1655-1658.

6. Shimokawa, K., H. Kadowaki, H. Sakura, S. Otabe, R. Hagura, K. Kosaka, Y. Yazaki, Y. Akanuma, and T. Kadowaki. 1994. Molecular scanning of the glycogen synthase and insulin receptor substrate-1 gene in Japanese subjects with non-insulin-dependent diabetes mellitus. Biochem. Biophys. Res. Commun. 202:463-469.

7. Hitman, G.A., K. Hawrami, M.I. McCarthy, M. Viswanathan, C. Snehalatha, A. Ramachandran, J. Tuomilehto, E. Tuomilehto-Wolf, A. Nissinen, and O. Pedersen. 1995. Insulin receptor substrate-1 gene mutations in NIDDM: implications for the study of polygenic disease. Diabetologia. 38:481-486.

8. Celi, F.S., Tanner, K., Raben, N., F. de Paoblo, K. D. Silver, J. Walston, B. Mitchell, and A.R. Shuldiner. 1995. Two novel missense mutations in the insulin receptor substrate-1 (IRS-1) gene in Mexican Americans with NIDDM. Diabetes. 44:155. (Abstr.).

9. Humphreys, P.J., H. Lewis, I. Stratton, R. Morgan, and S. O'Rahilly. 1995. Novel missense mutation in insulin receptor substrate 1 in a patient with severe insulin resistance affects the YMXM motif interacting with PI 3-kinase. Diabetologia. 38:123. (Abstr.).

10. Clausen, J.O., T. Hansen, C. Bjorbaek, S.M. Echwald, S.A. Urhammer, S.B. Rasmussen, C.B. Andersen, L. Hansen, K. Almind, K. Winther, J. Haraldsdòttir, K. Borch-Johnsen, and O. Pedersen. 1995. Insulin resistance: interactions between obesity and a common variant of insulin receptor substrate1. Lancet. 346:397-402.

11. Myers, M.G., Jr., X.J. Sun, and M.F. White. 1994. The IRS-1 signaling system. TIBS (Trends Biochem. Sci.). 19:289-293. 
12. Backer, J.M., M.G. Myers, Jr., X. Sun, D.J. Chin, S.E. Shoelson, M. Miralpeix, and M. F. White. 1993. Association of IRS-1 with the insulin receptor and the phosphatidylinositol 3'-kinase. J. Biol. Chem. 268:8204-8212.

13. Sun, X.J., M. Mirelpeix M.G. Myers, Jr., E.M. Glasheen, J.M. Backer, C.R. Kahn, and M.F. White. 1992. Expression and function of IRS-1 in insulin signal transmission. J. Biol. Chem. 267:22662-22672.

14. Giorgetti, S., R. Ballotti, A. Kowalski-Chauvel, S. Tartare, and E. Van Obberghen. 1993. The insulin and insulin-like growth factor-I receptor substrate IRS-1 associates with and activates phosphatidylinositol 3-kinase in vitro. J. Biol. Chem. 268:7358-7364.

15. Noguchi, T., T. Matozaki, K. Horati, Y. Fujioka, and M. Kasuga. 1994. Role of SH-PTP2, a protein-tyrosine phosphatase with Src homology 2 domains in insulin-stimulated Ras activation. Mol. Cell. Biol. 14:6674-6682.

16. Baltensperger, K., L.M. Kozma, A.D. Cherniack, J.K. Klarlund, A. Chawla, U. Banerjee, and M.P. Czech. 1993. Binding of the ras activator son of sevenless to insulin receptor substrate-1 signaling complexes. Science (Wash. DC). 260:1950-1952.

17. Skolnik, E.Y., A. Batzer, N. Li, C.-H. Lee, E. Lowenstein, M. Mohammadi, B. Margolis, and J. Schlessinger. 1993. The function of GRB2 in linking the insulin receptor to ras signaling pathways. Science (Wash. DC). 260:19531955.

18. Myers, M.G., Jr., L. Wang, X.J. Sun, Y. Zhang, L. Yenush, J. Schlessinger, J.H. Pierce, and M.F. White. 1994. Role of IRS-1-GRB-2 complexes in insulin signaling. Mol. Cell. Biol. 14:3577-3587.

19. Folli, F., M.J.A. Saad, J. Baker, and C.R. Kahn. 1993. Regulation of phosphatidylinositol 3-kinase activity in liver and muscle of animal models of insulin-resistant and insulin-deficient diabetes mellitus. J. Clin. Invest. 92:17871794.

20. Cheatham, B., C.J. Vlahos, L. Cheatham, L. Wang, J. Blenis, and C.R. Kahn. 1994. Phosphatidylinositol 3-kinase activation is required for insulin stimulation of pp70 S6 kinase, DNA synthesis, and glucose transporter translocation. Mol. Cell. Biol. 14:4902-4911.

21. Wang, L., M.G. Myers, Jr., X. Sun, S.A. Aaronson, M. White, and J.H. Pierce. 1993. Irs-1: essential for insulin- and Il-4-stimulated mitogenesis in hematopoietic cells. Science (Wash. DC). 261:1591-1594.

22. Pierce, J.H., M. Ruggiero, T.P. Fleminf, P.P. Di Fiore, J.S. Greenberger, L. Varticovski, J. Schlessinger, G. Rovera, and S.A. Aaronson. 1988. Signal transduction through the EGF receptor transfected in IL-3-dependent hematopoietic cells. Science (Wash. DC). 239:628-630.

23. Ho, S.N., H.D. Hunt, R.M. Horton, J.K. Pullen, and Larry R. Pease. 1989. Site-directed mutagenesis by overlap extension using the polymerase chain reaction. Gene. 77:51-59.

24. Morgenstern, J.P., and H. Land. 1990. Advanced mammalian gene transfer: high titre retroviral vectors with multiple drug selection markers and complementary helper-free packaging cell line. Nucleic Acids Res. 18:35873596.

25. Pear, W.S., G.P. Nolan, M.L. Scott, and D. Baltimore. 1993. Production of high-titre helper-free retroviruses by transient transfection. Proc. Natl. Acad. Sci. USA. 90:8392-8396.

26. Myers, M.G., Jr., L. Wang, X.J. Sun, Y. Zhang, L. Yenush J. Schlessinger, J.H. Pierce, and M.F. White. 1994. Role of IRS-1 complexes in insulin signaling. Mol. Cell. Biol. 14:3577-3587.

27. Saad, M.J.A., F. Folli, and C.R. Kahn. 1995. Insulin and dexamethasone regulate insulin receptors, insulin receptor substrate-1 and phosphatidylinositol 3-kinase in Fao Hepatoma cells. Endocrinology. 136:1579-1588.

28. Ura, S., E. Araki, H. Kishikawa, T. Shirotani, M. Todaka, S. Isami, S. Shimoda, R. Yoshimura, K. Matsuda, S. Motoyoshi, et al. 1995. Molecular scanning of the IRS-1 gene in Japanese patients with non-insulin-dependent diabe- tes mellitus: identification of five novel mutations in IRS-1 gene. Diabetologia. In press.

29. Backer, J.M., M.G. Myers, Jr., S.E. Shoelson, D.J. Chin, X. Sun, M. Miralpeix, P. Hu, B. Margolis, E.Y. Skolnik, J. Schlessinger, and M.F. White. 1992. Phosphatidylinositol 3'-kinase is activated by association with IRS-1 during insulin stimulation. EMBO (Eur. Mol. Biol. Organ.) J. 11:3469-3479.

30. Waters, S.B., K. Yamauchi, and R.E. Pessin. 1993. Functional expression of insulin receptor substrate-1 is required for insulin-stimulated mitogenic signaling. J. Biol. Chem. 268:22231-22234.

31. Araki, E., M.A. Lypes, M. Patti, J.C. Bruening, B. Haag III, R.S. Johnson, and C.R. Kahn. 1994. Alternative pathway of insulin signaling in mice with targeted disruption of the IRS-1 gene. Nature (Lond.). 372:186-190.

32. Tamemoto, H., T. Kadowaki, K. Tobe, T. Yagi, H. Sakura, T. Hayakawa, Y. Terauchi, K. Ueki, Y. Kaburagi, S. Satoh, et al. 1994. Insulin resistance and growth retardation in mice lacking insulin receptor substrate-1. $\mathrm{Na}$ ture (Lond.). 372:182-186.

33. Patti, M., X. Sun, J.C. Bruening, E. Araki, M.A. Lipes, M.F. White, and C.R. Kahn. 1995. 4PS/IRS-2 is the alternative substrate of the insulin receptor in IRS-1 deficient mice. J. Biol. Chem. 270:24670-24673.

34. Sun, X.J., L.M. Wang, Y. Zhang, L. Yenush, M.G. Myers, Jr., E. Glasheen, W.S. Lane, J.H. Pierce, and M.F. White. 1995. Role of IRS-2 in insulin and cytokine signaling. Nature (Lond.). 377:173-177.

35. Cheatham, B., and C.R. Kahn. 1995. Insulin action and the insulin signaling network. Endocrine Rev. 16:117-142.

36. Denton, R.M., and J.M. Tavare. 1995. Does mitogen-activated-protein kinase have a role in insulin action? The cases for and against. Eur. J. Biochem. 277:597-611.

37. Rordorf-Nikolic, T., D.J. Van Horn, D. Chen, M.F. White, and J.M. Backer. 1995. Regulation of phosphatidylinositol 3'-kinase by tyrosyl phosphoproteins. J. Biol. Chem. 270:3662-3666.

38. O'Neill, T.J., A. Craparo, and T. Gustafson. 1994. Characterization of an interaction between insulin receptor substrate 1 and the insulin receptor by using two-hybrid system. Mol. Cell. Biol. 14:6433-6442.

39. Deleted in proof.

40. Goodyear, L.J., Giorgino, F., L.A. Sherman, J. Carvey, R.J. Smith, and G.L. Dohm. 1995. Insulin receptor phosphorylation, insulin receptor substrate1 phosphorylation and phosphatidylinositol 3-kinase activity are decreased in intact skeletal muscle strips from obese subjects. J. Clin. Invest. 95:2195-2204.

41. Saad, M.J.A., E. Araki, M. Miralpeix, P.L. Rothenberg, M.F. White, and C.R. Kahn. 1992. Regulation of insulin receptor substrate-1 in liver and muscle of animal models of insulin resistance. J. Clin. Invest. 90:1839-1349.

42. Borkman, M., L.J. Storlien, D.A. Pan, A.B. Jenkins, D.J. Chrisholm, and L.B. Campbell. 1993. The relationship between insulin sensitivity and the fatty acid composition of skeletal muscle phospholipids. N. Engl. J. Med. 328: 238-244.

43. Hotamisligil, G.S., N.S. Shargill, and B.M. Spiegelman. 1993. Adipose expression of tumor necrosis factor- $\alpha$ : direct role in obesity-linked insulin resistance. Science (Wash. DC). 259:87-91.

44. Maddux, B.A., P. Sbraccia, S. Kumakura, S. Sasson, J. Youngren, A Fisher, S. Spencer, A Grupe, W. Henzel, T.A. Stewart, et al. 1995. Membrane glycoprotein PC-1 and insulin resistance in non-insulin-dependent diabetes mellitus. Nature (Lond.). 373:448-451.

45. Reynet, C., and C.R. Kahn. 1993. Rad: a member of the ras family overexpressed in muscle of type II diabetic humans. Science (Wash. DC). 262:14411444

46. Rothenberg, P.L., L.D. Wilson, J. Simon, and B.A. Wolf. 1995. Glucose induced insulin receptor tyrosine phosphorylation in insulin-secreting betacells. Diabetes. 44:802-809. 